DOI: 10.2478/ausfm-2019-0017

\title{
Veterans and Grannies. The Polyphony of Memory in Two Hungarian Documentary Films
}

\author{
Réka Sárközy \\ National Széchényi Library, 1956 Institute (Budapest, Hungary) \\ E-mail: sarkozy.reka0411@gmail.com
}

\begin{abstract}
The essay analyses the representation of polyphonic memory in two groundbreaking Hungarian documentary films, made thirty years apart: János and Gyula Gulyás’s I was at the Isonzo, too (Én is jártam Isonzónál, 1984-87) and Bálint Révész's Granny Project (Nagyi projekt, 2017). The earlier film was made in the 1980s, under the state-socialist system, when doing memory work of both World Wars was limited, if not forbidden. The second film was made recently, in 2017. They differ from each other in many ways, but instinctively they chose the same solution for representing and working out traumas: through transnational dialogue. They focus on traumatic experiences of the past, changing national, so-called monologic memory into a broad perspective, putting Aleida Assmann's (2005) theory of dialogic memory into practice. ${ }^{1}$
\end{abstract}

Keywords: First World War, Second World War, Holocaust, polyphonic memory, dialogic memory, sense memory.

Documentary as well as feature films can mediate between subjectivity and history, as Thomas Elsaesser writes, "films have proved to be extraordinary instrument for giving shape, texture and voice to a 'history from below' or 'everyday history' through the power of immediacy inherent in the moving image" (2001, 197). Film democratizes historical knowledge because it elevates alternative historical images next to the exclusive historical canon. These filmic narratives do not aspire to turn their own narrative into the only accepted one. Through the different mediums of memory building on each other and crossing each other, more complex structures come into existence in the different sources of media. Filmic narrative does not replace historical knowledge: "while memory is indispensable, as a view from the inside, to evaluating the events of the past

1 I am grateful to Judith Szapor for her help with the English translation of the original Hungarian text. 
and to creating an ethical stance, history is needed, as a view from the outside, to scrutinize and verify the remembered events" (Assmann 2006, 264).

The distance is seventy years: the two films analysed in this study both look back from that distance to the past but were made thirty years apart; János and Gyula Gulyás's film on the First World War I was at the Isonzo, too was made before the regime change, while Bálint Révész's film about his grandmother's memories (Granny Project) was released in December 2017. Both are groundbreaking in that they go beyond the national boundaries of memory work, and put the memories of the two World Wars in a transnational perspective.

The memory of the First World War came into the spotlight as a result of the recent anniversaries of its beginning and ending. It is already distant history, in the sense that everyone involved in it passed away decades ago. To catch the personal memories of the then still living witnesses at the last moment, in the film the Gulyás brothers accompanied some Hungarian WWI veterans to the shores of the river Isonzo - once the place of an infamous battle -, there on the invitation of an Italian city. This documentary, completed in 1987, has remained a unique attempt to grab the memory of the First World War in Hungary - and it has never been followed up by others. ${ }^{2}$ The film is unique in that it records the parallel memory of the Italian veterans as well, taking into consideration the polyphony of the traumatic experiences of war. Historian Gyula Juhász calls this film enchanting and it reminds him of Sándor Sára's documentary series Chronicle (Krónika, 1982), being deeply impressed by the testimonies of these old veterans (Juhász 1987). Zsolt Győri emphasizes the community of historical experience and the cohesion of the veteran group, forming a common identity in the film (Győri 2015).

The Granny Project by Bálint Révész, completed over thirty years later, in the last months of 2017 , is a fresh, contemporary work of art that weaves together the complex dialogue of its subjects, the three members of the crew and their grandmothers in a very suggestive way. The film turned out an international success: won Best Documentary Feature Prize at the Minsk International Film Festival in 2018, and also won at the Taiwan International Documentary Festival

2 "We did not try to make scholarly discoveries, we just wanted to evoke the often mentioned 'ordinary people's' extraordinary spirit, but also weakness and to share it with ourselves and those following us, to preserve the fate and experiences of the late hussars, sappers, gunners, lived through at the dawn of this century, experiences often falsified or denied later. We wanted to see our ancestors, and also our future paths" - declared the filmmakers according to a blog recommending the film. See: A magyarok és az első világháború. Filmtörténeti kutatás [Hungarians and the First World War. A Film Survey]. Filmajánló blog http://hosokvoltak.blog. hu/2011/06/22/filmajanlo_magyarok_es_az_i_vilaghaboru. Last accessed 05. 08. 2019. 
in the same year. The film was awarded the Prize for Best Editing and for Best Documentary by the Hungarian Critics in the same year. Many agree that this is the film after which "one must call and embrace her granny” (Bújdosó 2018; Rácz 2018). The creators and their grannies hail from three nations: they are German, British, and Hungarian, with the last one, the grandmother of the director, a Holocaust survivor, to boot. The three brave old ladies keep trying to follow a shared process of understanding as they evoke their stories of the Second World War and its consequences. The film places all these characters into a complex web of relationships. The old ladies accept their assigned roles, and for the sake of their grandsons try to understand the past and the still intensely emotional influence that has on their lives. The great invention of this film is that the physical presence of the others forces the interviewees to listen to each other, and reflect on the others' perspective. Winner and loser, perpetrator and victim, all have hidden but continuous confrontations. Against their will, their grandsons put them at times in almost unbearably uncomfortable, trap-like situations getting out of which calls for their greatest efforts. An outstanding merit of the film is proving that it is worth trying, that the attempt of the three old women to approach the others, despite the tensions, awkwardness, and at times forced turns, carries the potential of a solution.

The filmmakers appear on camera in both films, and they are acting in them, but in a different way. According to Bill Nichols's documentary typology, the Gulyás brothers' Isonzo film is rather a participatory documentary; it stresses the actual, lived encounter between the filmmakers and their subjects, the WWI veterans. Gyula Gulyás makes a maximum effort to improve his "in situ” role as "mentor, critic, interrogator, collaborator or provocateur" in the filming process (Nichols 2001, 116) to reveal the almost forgotten history of WWI.

The young filmmaker, Bálint Révész also participates in his film, but in a different way: he interacts in a rather provocative manner, as a performative documentary filmmaker, to "emphasize and construct the hidden aspects of performance, either on the part of the documentary subjects or the filmmakers" (Bruzzi 2000, 153). Hungarian documentary films made about the Holocaust ${ }^{3}$ mostly present the perspective of the victim, use oral history, and perhaps influenced by Lanzmann's groundbreaking saga on Holocaust, Shoah (1985), are made in participatory mode - to apply Bill Nichols's typology (2009, 20-42).

3 Some examples: Gyula Gazdag’s Package Tour (Társasutazás, 1984), János Szász's The Eyes of the Holocaust (A holokauszt szemei, 2000), Ágota Varga's Porrajmos, Gypsy Holocaust (Porrajmos. Cigány holokauszt, 2000), Anna Mérei’s A Guardian Angel’s House (Órangyalház, 2001), Richárd Schuszter's Three Missing Pages (Három hiányzó oldal, 2007). 
Bálint Révész's documentary also brings novelty to the genre. Bruzzi warns that performance, dramatization and acting for the camera can undermine the conventional documentary pursuit of representing the real (Bruzzi 155), nevertheless, this film proves to be a trustworthy work of art because its fundamental issue remains honesty, curiosity and love till the last. Documentary film faces a double problem in representing traumas: it makes an attempt to reconstruct previously silenced events of the past - topics forbidden for public discussion in the earlier decades, while on the other hand, it also has to show what happened in the psyche of the community that suffered trauma, how they experienced the tragic event (Stôhr 2011). Performative and participatory documentaries can be good solutions for this double challenge. A third problem is that introducing a new historical issue into cultural memory is not an easy task. Aleida Assmann emphasizes that when a national community faces the negative experiences of the past, there remain just three roles to perform: that of the winner, defeating the evil, the heroic fighter, who resists evil, and the victim, who suffers the tortures of the evil innocently $(2012,16)$. Everything else is forgotten. According to Gábor Gyáni (2013, 204), this heroic role is represented in Hungarian historical consciousness by a few selected events: prehistory, the conquest of Hungary, the Second World War, the Trianon Treaty, and the Revolution of 1956.

Neither the history of the battles of the First World War, nor the Holocaust figures on this list, and both documentaries make an effort to incorporate these into the historical and also the documentary narrative. The reason for the absence of the First World War and the Holocaust from the subjects of collective memory and also the filming narrative was historical. The history of the Second World War and of the 1950s in Hungary were a taboo until the 1980s. The documentary film series that broke this silence, Sándor Sára's Chronicle was broadcast on Hungarian Television in 1982 and told the story of the destruction of the Hungarian Second Army at the Don Bend in 24 episodes. It put the survivors of history into the role of authentic witnesses, and the screening of the series on Hungarian state television glued the viewers to the screen night after night. A few years later, in the mid-eighties, the silenced, previously forbidden topics of the recent past, mainly the stories of the Stalinist 1950s came into focus in the films produced by the Balázs Béla Studio, Budapest. The story of a show trial in a case of accidental death in Judit Ember's Pócspetri (1983), the secret of a work camp in Lívia Gyarmathy and Géza Böszörményi’s Recsk (1988), the testimonies of forced internment in the Gulyás Brothers' Without Breaking of the Law (Törvénysértés nélkül, 1988) were documentaries created about the most 
important historical taboos. Documentary films had a crucial role in starting discussions about these taboos and thus breaking them. "This unique period in the history of Hungarian documentary film was created by the opportunity that [offered itself] in a social environment still in flux, [when] people, even those who had served the communist dictatorship, were willing to appear and share their opinion in front of the camera. We will not see the number of films based on facing the past, made during the dissolving socialist regime equalled until the end of the 1980s - understandably, due to the memory politics of the socialist regime built on silence and distortion -, or even following the early 1990s." (Murai 2015.) The prohibiton of representing 1956 in a documentary was still in force until the regime change in 1989. The Trianon Treaty and the Holocaust were on the margins of accepted subjects. The memory of the front lines of the First World War had been overshadowed by the memory of the Trianon Treaty, and thus, without a realistic resolution, it became the impetus for a new nationalism, and remained fixed in the memory mode that Jan Assmann calls "hot memory" (2011, 50-53). The Gulyás brothers' film is the first and, to this day, the only Hungarian documentary film about the First World War.

These films opened up a taboo of the previously concealed past, making it public: it is thanks to them that people could finally mourn their relatives, the soldiers lost in WWII, the victims of the Holocaust, or the victims of the political violence of the 1950s. "These visually puritanical works of art mainly shot in seconds were made exciting through the staging of parallel memories. That was the reason, apart from their thematic relevance, why they became so special in their methods." (Murai 2015.) They built up the audiovisual memories of the hidden and suppressed terror of the past. The force of the films originated from "the screen with a face that is expressive and concrete, individual and memorable, as the voice is speaking” (Assmann 2006, 265). The narrative frame of the Gulyás brothers' film is a package tour to the former battlefield, taking place in 1984. Visiting the place of the former trauma to catalyse the process of memory is used by another important film of the same year. A group of survivors visited Auschwitz, and Gyula Gazdag directed one of the first, important documentary films on the Holocaust in Hungary, entitled Package Tour (Társasutazás, 1984).

Witnesses embodying the role of historical sources helped these films reveal the past at a time when access to written sources was restricted, and historians could not cross the boundaries defined by the Soviet-type regime of the Kádár era. After the 1989 regime change, sources became accessible, and the documentary film lost its function as a historical source, yet preserved its role as a special oral 
history. The historical documentary films made after the regime change, based on long oral history-type interviews, lost their legitimacy because they did not fulfil such an important role in society as they did in the 80s. But this role and its canonized visual tradition continued to have a strong impact on filmmakers, although the documentaries themselves would be barely watchable for the viewer today. The static pictures built around "talking heads" are dated, and their content became similarly dated.

Unlike most of the historical documentaries of the 80s, the Gulyás brothers often filmed by shoulder-mounted shooting. "We knew that we must not film a man just sitting: we had to show his environment, his activity, work, his coming in and around, to show his way of life, to make a difference between a teacher and a mechanic, a retired upholsterer, etc." (Szekfú, 2014). In the Isonzo film and Gyula Gazdag's Package Tour it was obvious that the filmmakers had to be on the move looking for the best angle, the most cathartic moments, and detect the situations worth for filming. The filmmaker, the "second witness" records their testimony with empathy, trying to use as little technical support as possible. In that period, documentaries were filmed with $35-\mathrm{mm}$ and $16-\mathrm{mm}$ film cameras: heavy equipment, difficult to work with in the field. Filmmakers, including the Gulyás brothers made a tremendous physical effort to create intimacy and closeness during the shootings. They also participated in the film, and with "performative moments" they drove us "into the subjective, 'as if' renderings of traumatic past events" (Nichols 2001, 132). As a result, they could build up a linear history and also gain a private testimony of the witnesses.

The new generation of filmmakers is in a much better technical situation: light handycams, wireless microphones support their work to create filming situations that are intimate and playful. Historical documentaries do not concern themselves at all with research or the facts of the past; identity and its construction became their focal point, and history can only offer some bricks to build on this process. Their "performative documentaries primarily address us [the audience], emotionally and expressively, rather than pointing us to the factual world we hold in common" (Nichols 2001, 132). Nowadays the valid and exciting question is "What happened to me?" in order to get to the final question: "Who am I?" They themselves want to understand past emotionally because they find that something integral to the experience of the past is lost, when they try to rely simply on the facts of history. Jill Bennett emphasizes the difference between "common memory" and "sense memory," and the importance of the latter in visual art, for the imagery of traumatic memory deals not simply with a past event, or 
with the objects of memory, but with the present experience of memory, too. The main difference is that while ordinary memory is properly representational and connected with the thinking process and with words, sense memory "operates through the body to produce a kind of 'seeing truth,' rather than 'thinking truth' registering the pain of memory as it is directly experienced and communicating level of bodily affect" (Bennett 2005, 29). Documentary film is an ideal medium, where "the two realms of memory" - sense memory and common memory - can work in a kind of dialectical relationship with one another.

Up until very recently - and in most countries even to this day - the only valid framework to narrate history was national. Nowadays this seems to have changed a bit in Europe, where places of memory with multiple focal points are being established; these are more self-reflective and less normative or confident than their national narrative-based equivalents. Moreover, they focus on traumatic and debated topics, such as the history of the Second World War and the Holocaust. In spite of the decades already past, these debates have not resulted in a national consensus; this has been especially the case in Eastern Europe, including Hungary, where the participation in the Second World War and, along with Poland, the responsibility for the Holocaust are still hotly debated historical episodes. Surprisingly, when a historical study of a pogrom committed by the Poles in 1941 in Jedwabne was published sixty years after the event, it became a milestone in Polish national memory work. The debates of that case helped the transnational approach to memory work strengthen (Deák 2002). It was realized that dialogue, previously refused by the national community, can point to gaps in the memory work or shed light on subjects previously neglected.

National memory, focusing on heroism, calls on selected sources to support crucial events of national identity. These are destined to serve their own end; if mixed up with political myths they can serve as a shield against exactly those traumatic experiences which would otherwise be forgotten by the nation (Assmann 2012). Memory work has not overcome national frames of historical narratives in Hungary - that is exactly why these two documentaries are important and valuable. "Video testimony" - according to Aleida Assmann - is a dialogic medium itself: it depends for its process on the guidance of the filmmaker who asks questions and supplies responses as well. It also leaves room for open-ended passages, such as pauses, periods of silence, uncompleted sentences, innuendo $(2006,265)$. Words and visual registers are complementing each other: words are on the side of thought for registering common memory, and when it cannot be spoken as it is felt - it may register images and sense memory (Bennett 2005, 31). 
In the film of Bálint Révész, the central memory problem is the Holocaust. The problems of Hungarian historical consciousness, the amnesia of Hungarian society, and the unfinished memory work make the Holocaust a "hot memory" in Hungary. Even as it is leaving communicative memory, as its survivors (and perpetrators) pass away, it is not able to transform into cultural memory. This uneasiness was highlighted on the $70^{\text {th }}$ anniversary of the Holocaust in Hungary: the WWII memorial at Szabadság Square Budapest refused by the Jewish community and Yad Vashem, as well as the unfinished and still empty House of Fates Museum (Sorsok Háza) also in Budapest are both obvious evidence of that (Heisler 2015).

Aleida Assmann was not the first who realized the advantage of polyphonic past in the elaboration process. Researching the memory of the Holocaust, Saul Friedländer distinguished two strata of memory. According to him, the memory of the Holocaust that lives in the human subjects is a so-called deep memory and comes to the surface as a common or shared memory. The trauma of the Holocaust survives in deep memory as something undissolved and unpresentable, while the visible, common form of memory reconstructs or develops the context in the narration - although this kind of memory work can never be completed. Every attempt trying to shape a coherent self runs to the ground because of the repressiveness of deep memory (Friedländer 1992, 41). Friedländer suggests that historians construct a narrative frame to include both memory strata. In this integrated historiography the researcher's explanations should elaborate on the narration's simple linearity and present alternative interpretations, querying every prejudiced explanation, and resist the demand of closure (Friedländer 1993, 132).These interruptions put the reader off and remind them that history is just a construction: one person's interpretation. This kind of alienation effect is used in both films. They both keep trying to signal the presence of deep memory, but they have to face the inability of their interviewees to transmit the totality of their memories. Still, by involving the memory of the victims, we get a polyphonic interpretation of the past. Narration is not linear and indisputable, but multiple. The dialogue between and about the victims can make space for the elaboration process. The filmmakers are both aware of that and realize their own responsibility in this process. Deep memory preserves its hidden nature, it is almost impossible to grab and make visible. Spiritual elaboration is nothing else than watching the missing meaning, according to Friedländer (1992, 55). Documentary films are ideal mediums to make deep memory visible or at least perceptible, and the analysed films are good examples of that effort. The emotional outbreaks of deep memory can be comprehensible as outcrops of Bennett's sense memory. 
The film of the Gulyás brothers represents a case of shared memory work, accomplished by an ad hoc group of veterans in their attempt to help deep memory or sense memory come to the surface. They physically take on a long journey but also one in their minds. The acts of boarding and travelling on the bus catalyse their memories and call them to the surface. The time spent together during the journey makes memories, long ago buried surface, and makes them possible to be worked out. Stories of bravery and the step-by-step tracing of the battle offers the chance to recall traumatic experiences for the veterans, on their package tour to the river Isonzo. Besides the stories of suffering, it is still important for the former soldiers to have their heroism recognized.

„Hungarians fought with enthusiasm and devotion up to the total collapse.”

"We were not defeated. That Italian army would never have beaten us. If only we had bullets and food."

"We didn't lose the war because we were cowards. That was not the reason. The Italians said that we should stop fighting, so they would stop it too. We, Hungarians were ready to do that, but the Austrians and the French were not. They all wanted to fight on."

The common denominator with the Italians is the collective suffering, the unnecessary sacrifice on both sides, and humanity. From this starting point, the men representing the two countries, once enemies, are able to listen to each other and can accept the other side's pain and sorrow. Most of them became prisoners of war, and their memories are mostly from that period. Stories of positive and negative experiences alternate with each other, not fighting, but rather nuancing the picture of the Italian army in a new way. The most important question they raise is who the real enemy was: everyone who wanted to continue fighting. Some take a personal responsibility for that. The greatest criminal is war itself.

Not all Hungarians talk positively about the Italians - one recalls the flowerpots thrown at their back while they were marching through the villages. But his story is followed by another, more tolerant point of view about the same event, describing the emotions of the civilian population. There is no consent on anything, on the contrary, controversial memories, loud arguments, clashes of divergent constructions follow each other. They have no patience to listen, and very deep, long-repressed memories come to the surface. The fact is that these old men, arguing on the banks of the river Isonzo cannot tolerate the others' perspective. Thomas Elsaesser remarks that subjectivity to history is a problem and has to be re-thought by contemporary trauma theory because "witnessing and personal testimony are in some sense both crucial and highly problematic. 
Crucial, because participants, especially in the 'memory wars' are often embroiled in wanting to claim: 'My act of testimony is my truth [...].' Problematic, in that such a truth is specific and local, but it may lack narratives" (Elsaesser 2011, 198). But that still does not reduce the value of the survivors' memories. "I don't talk rubbish, what I'm telling is the truth" - says one of them. And it is true - for him, a deeply experienced reality, its coherence is measured by an inner scale. This is the paradox nature of oral history: as a historical source it is unreliable, but as evidence of the trauma survived it is authentic and unquestionably true.

There are just a few Italians speaking in the film - Hungarians are clearly the priority for the filmmakers. The Italians are very enthusiastic to meet them, they show sincere curiosity. For them the negative experience of the Hungarian contribution to the First World War is overwritten by the positive, heroic memory of the Hungarian Hussars fighting on the side of Giuseppe Garibaldi. They do not talk too much, but the event to which the Hungarians had been originally invited provides a meaningful gesture: a common Christening. At the end of the ceremony the priest asks the veterans on both sides to shake hands. The emotional scene of a shy embrace is followed by catharsis: the slow-motion shot ends on the close-up of a veteran who struggles with his tears. The same soldiers who did not doubt the necessity of the Hungarian participation in the war, after the long emotional - and also physical - journey taken to the river Isonzo, confirm the senselessness of war.

"It was not our will. There had always been a great power above us, which commanded us. It was forbidden to step out of the line. That was the law."

In the closing shot of the Isonzo film, we see a weeping old man standing on the riverside after the celebration. Beside him local Italian teenage boys are awkwardly smiling at him. Sense memory comes to surface here, it touches the viewer, who feels, rather than simply sees the old man in tears. These last moments of the film can be understood in several ways. The young boys' distracted reaction, their squirm can be taken as a recoil, "a moment of regrouping the self" and it also "lets us feel the visual, but also maintain a tension between self and image" (Bennett 2005, 37). We can see them as frowning, and their smile as offensive. But we can also assume that they are faced with something distant and strange for the first time in their life, and they cannot understand it, and their smile merely registers their embarrassment (Szekfü 2014).

In this image there is the promise of a continuation: the sight of the veteran may raise questions in the boys, they might even approach him. This move actually happens in Bálint Révész's film, he develops the encounter of the two 
generations into a film, thirty years later. The young artists filming their grannies are just a few years older than the Italian teenagers on the bank of the Isonzo, and in this more recent film they become the protagonists and filmmakers. Still, an air of embarrassment follows them in their journey of discovery that they had taken up with the film. But they also accept being moved, their sentiments are in constant flux. This polyphony makes the pain of understanding and facing the past visible but also asks the audience to remain patient and tolerant, not to judge the difficult task of either facing or approaching the past.

Bálint Révész's film rests on polyphonic ground: the filmmaker trio originates from three different countries. Their aim was to grab this polyphony and to explore common points in it. They try to leave behind the canonized narrative form as they feel their message cannot be wedged in it. But they do not want to renounce the representation of the past: they rather attempt to change that totally. "We cannot connect ourselves to the past because everybody answers its questions with groans, serious faces, looking onto the floor with crossed legs. This is exactly what this film is targeting: we don't want to be polite because they (our grannies) are almost gone. In twenty years this whole thing would be like the French revolution: everybody who went through it, would be dead. This is a language, invented by us, to talk about such topics. It's upon us how joyfully but seriously we use it. It's just necessary to talk about it." (Pozsonyi 2017.) The acts of the filmmakers are provocative: the three silly, clowning young artists constantly make fun of themselves and of the filming situation. They literally drag their grandmothers into the project: they drive, escort, push them in their wheelchairs through countries, situations, places of the past and the present, generating the process of bringing memory to light. They are the receivers, "the secondary witnesses" of the testimonies. Their grannies depend on them to understand the historic significance of the testimony and make it public. "The appeal in this case is not to a divine authority but to humanity at large, which - to the extent that it registers and memorializes the event - constitutes itself as a moral community." (Assmann 2006, 269.) The common moral ground of the filming is inarguable, maybe that is why the grannies tolerate it quite well, although with emotional ups and downs. Sometimes they quarrel with the youngsters, at times even protest, and a few times they shed a few tears. But they rarely oppose and even laugh a lot. The boys are not only interested in the events of the past, but, as time goes on, they also have to face the problem of losing their subjects. They care not only for the entangled relations of the beloved grannies in the past, their own relation with them has great importance, too. They also manage to find out 
whether the three women have succeeded in overcoming the past. The outcome is astonishing: the Holocaust survivor Hungarian grandmother is the only one who is able to work through the trauma. The three young filmmakers, Bálint Révész, Meredith Colchester and Ruben Woodin Dechamps are fully present in the acts of the film. The boys, born around the regime change of 1989 have problems with the past themselves. Naturally, they analyse themselves in the story, their purpose is to understand their reactions to the stories of war, guilty conscience, sufferings. And they are helped by the strong, mutual ties of love that connect each pair of grandmother and grandson, without which this film could not have been made; after all, the boys put into impossible situations not only themselves but also their patient, open-minded grandmothers. Stella Bruzzi's assertion that the creators of performative documentary films participate in their works because they are interested in discovering alternative and less formally restrictive ways of getting to what they perceive to be the essence of their subjects, is confirmed in Bálint Révész's film. "The means by which they achieve this are not those conventionally associated with truth-finding post-direct cinema as they entail breaking the illusion of film, thereby interrupting the privileged relationship between the filmed subjects and the spectator.” (Bruzzi 2000, 163.)

Who are these grandmothers? The German grandmother remains quite enigmatic. She has a guarded personality, and so does her grandson. Her situation is the most difficult in the film: she struggles with the Nazi past of her family, and she is not very keen on talking about it. She denies her family's involvement with the Nazi Party, and this conversation has very obvious limits. Interestingly, her grandson shares her unwillingness to open up: he also refuses to ask certain questions, without offering an explanation to the other two boys. His stories are equally ambiguous: we never learn the degree to which his grandfather, founder of a religious sect, was involved in the Nazi Party. This communication failure shows that Germany's Nazi past is still a problematic question; it's not easy to admit collaboration with or even passive acceptance of the Nazi regime, even in such an open-minded, playful and fresh film, even for the young generation. Aging and forgetting provides a dramatic frame to their conversation, although, according to Assmann, "the dark page, whereon Memory writes her light-beam characters and makes them legible, were it all light, nothing could be read there" $(1996,131)$.

Seemingly, the British grandmother is in the easiest position: she is on the side of the winners and took personal part in the fight: she worked as a code breaker in Bletchley Park, and, on top of that, she continued her work for the Secret Service in the years of the Cold War. However, it turns out that even she could not escape being 
traumatized. She is responsible for the death of innocent people, a memory that she has never been able to work through, and she has not been able to cope with it.

The Hungarian grandmother is a Holocaust survivor. She is the only one of the three who was able to work through the historical trauma, and she seems to have learned to live with the past quite well. She is a well-balanced old lady, her wisdom helps to navigate not only the questions of her grandson, but also the sometimes awkward situations with the other two grandmothers. It also helps to answer the provocative question: "Is there anything positive resulting from the Holocaust?" Her answer is: Yes, maybe there is, but only for her, and if so, it is not possible to share, neither is there a moral lesson for anyone else in it. One can criticize the film because of this question: it can be regarded as a blasphemy, cheap provocation, and a theatrical gesture, one that evades a sincere answer. The answer provided by the grandmother could be the result of her wish to fulfil the grandson's expectation. And this is not the only provocation in the film. As a performative documentary, it keeps trying to make the scenes situative: at the location of the deportation from Hungary the young filmmakers enact a shooting game, then they visit a real shooting range to experience war; they go to a cemetery, and one of them lies in a burial plot. These gimmicks may bewilder some, but they can still revitalize the old-fashioned and rather stale form of historical documentary film, although also require an open mind from the viewers. This is the point where a performative documentary can be problematic, according to Bruzzi. Such films get "more fixated" on the director's "persona and as that persona increasingly dominates the documentaries' action, so the films subjugate their proposed subject matter to a more focused, insistent interest in the issues of performance and 'realness'”' (Bruzzi 2000, 178).

"How could you do this to me?"- asks the German grandmother, who is at once a member of the defeated nation and, possibly, guilty. She is in the worst moral situation when the grandmothers are introduced. In spite of that, at least the grandmothers all tried to overcome their inner limitations, and were able to pay attention to the other two, even though they could not understand them. The film does not force a solution for mutual understanding. It is enough to listen to the other and try to feel empathy.

Near the end of the film another ambiguous scene is performed. The German granny calls the Hungarian one on skype. She sends - visibly, but virtually soap bubbles to her. An awkward, quite artificial scene. We cannot be sure whose idea it was. The intention is obvious: it's a confession and the offering of a handshake. A virtual, symbolic, embarrassing and not necessarily genuine 
gesture. The Hungarian grandmother watches it, understands it, and in spite of her doubts, makes a decision. She enters into the game and catches the soap bubble. They are both surprised but also relieved. In spite of the staged gesture something happened, inner boundaries were overcome here for a moment. "In a film, in which all reliable significance is generated by the director, there remains a tension between the subject as before and after his arrival, and that is never fully resolved." (Bruzzi 2000, 172.) We do not know what follows this virtual encounter, what extent of changes were generated by the young filmmakers, if any.

The approach of memory in the Gulyás brothers' Isonzo film and in Bálint Révész's Granny Project is in many ways similar. They try to call forth the memories of the traumatic past from a 70-year distance. They both chose traumatic events - the history of the front lines of the First World War and the Holocaust -, events that are still unresolved in Hungarian collective memory, and where memory work is still missing. The question is whether it is also possible to succeed with more distant traumas, several generations away from the events, like the First World War was in the 1980s or the Second World War is today. These events are both over the threshold of a two-generation gap - that is, 30-40 years - after the trauma, which is considered to be the ideal distance for memory work. The above discussed two documentary films prove that memory work is also possible much later than two generations after the event. During the long process of shooting, with their personal participation in the filming process on shared journeys, almost living together with their interviewees, the filmmakers try to force the unpresentable, deep memories to come to the surface. They know it takes time, but the outcome in both films is the experience of the emotional, polyphonic voice of the past. The Gulyás brothers accept the inaccuracy of memories, but they also know that talking about them can bring relief. Their source of authenticity comes from the broad tableau of the interviewees. The alternating memories and the debates of the interviewees strengthen and nuance their credibility, but not discredit them. The level of participation of the two filmmakers (Gulyás and Révész) in the documentaries is different. Originally through the personal memories of WWI veterans Gyula Gulyás was rather curious of historical truth. He was deeply influenced by the oral historical function of the Hungarian historical documentaries of the 1980s, but gradually, his interest turned to the recording of personal trauma, shared by Hungarians and their former enemies as well. Bálint Révész does not settle for the classical participatory role of the interviewer, he involves himself and his colleagues deeply and personally in the filming process, creating a classic example of a performative documentary. 
He is not interested in the facts, rather, in how those were experienced by his granny. With his provocative style, he also invokes deep memory. Thirty years apart, the two filmmakers as "secondary witnesses" achieve their goals: emotional and genuine personal testimonies are the outcome, shared with them, as well as with the public. In the moments of these memory outbreaks sometimes words are lost, emotion becomes the main motif, film technic makes sense memory impressive and visible for us. Sometimes these affective pictures are provoked by staged events (the Christening scene in the Isonzo film) or by the filmmaker (the picnic of the three old ladies and their grandchildren), which, however, does not ruin the authenticity of the vision. In our days dialogic memory may displace monologic, national memory, which is an exclusively self-reflective way of doing memory work. This is highly important because memory work can help get over the trauma of a violent past; furthermore, comparing the different strategies and images of the past can help solving the conflicts posed by that. The two films follow different paths to represent the dialogues of memory, for they were made thirty years apart, and the relation to memory has changed in the meantime. The Gulyás brothers primarily wanted to preserve the memory of the Hungarian WWI veterans before it sank into oblivion. The renewal of Hungarian historical documentary, enclosed in its tradition, remains to be accomplished by a new generation. The film of Bálint Révész sends a strong signal in that direction. In the opening scene of the film we can see the three boys from below: they are jumping up and down on an icy pond, literally trying to break the ice. It is clear that they want to break down the walls of the past and of silence with elemental force and energy. But the boys' action might also be construed as symbolic: by breaking the canonized forms of rigid tradition, they want to reach us, the viewers. This is completely different from the Isonzo film's slow progress into the story with its long dialogues. And yet, there are common problems both directors face, although they may think about the relation between documentary and history in a totally different manner. The polyphony of memory is an outstanding example to this. The Gulyás brothers probably came upon it instinctively; they had the intuition that documentary film is a unique medium to integrate two or even more perspectives (the interviewees' different pictures of the past blend with each other) and also to reflect on those. A new perspective is brought in by the personality of the filmmakers as well. They also realize that differences do not matter because those are overwritten by the collectively suffered war trauma.

This experience of their filmmaker predecessors is a learned skill for Bálint Révész. The three young filmmakers were probably aware of the importance 
of polyphony from the very first moment, exactly because of their personal involvement: even the film crew is international; intercultural communication is a daily practice for them. During the filming process, Révész realizes that the traumas and conflicts of the past can also be discussed from diverse perspectives, coming from different sources, and the only way to relief for all participants is to listen to the other. The Gulyás brothers' film anticipates the "invention" of dialogic memory at a time when the theory of memory has not been articulated yet. In both films the directors realize that the other side's story does not harm personal and national memory work: merely rethinks it, confronts it with another structure. The narrator who suffered trauma does not limit his perspective to a heroic or sacrificial picture of the self; on the contrary, he admits historical violence, the trauma, and reinterprets those within the frames of historical accounts. The recorded and sometimes forced dialogues with the filmmaker can lead to further questions to be asked, and help society achieve a greater degree of memory work.

\section{References}

Ambrosewitz-Jacobs, Jolanta. 2012. The Holocaust, and Coming to Terms with the Past in Post-Communist Poland. Ina Levine Annual Lecture 25. April. Washington, D.C.: United States Holocaust Memorial Museum, Center for Advanced Holocaust Studies. https://www.academia.edu/15339670/ The_Holocaust_and_Coming_to_Terms_with_the_Past_in_Post-Communist_ Poland._INA_LEVINE_ANNUAL_LECTURE_25_APRIL_2012?auto=download. Last accessed 05. 08. 2019

Assmann, Aleida. 1996. Texts, Traces, Trash. The Changing Media of Cultural Memory. Representations (Special Issue: The New Erudition) no. 56: 123-134. Assmann, Aleida. 2005. Személyes visszaemlékezés és kollektív emlékezet Németországban 1945 után [Personal Memory and Collective Memory in Germany after 1945]. In Holokauszt: Történelem és emlékezet [Holocaust: History and Memory], ed. Kovács Mónika, 355-363. Budapest: Jaffa Kiadó. Assmann, Aleida. 2006. History, Memory, and the Genre of Testimony. Poetics Today vol. 7, no. 2: 261-273.

Assmann, Aleida. 2012. Az emlékezet átalakító ereje [The Transformative Power of Memory]. Studia Litteraria vol. 51, no. 1, 8-22.

Assmann, Jan. 2011. Cultural Memory and Early Civilization: Writing, Remembrance and Political Imagination. Cambridge: Cambridge University Press. 
Bennett, Jill. 2005. The Aesthetics of Sense Memory. Theorizing Trauma through the Visual Arts. In Memory Cultures: Memory, Subjectivity, and Recognition, eds. Susannah Radstone and Katherine Hodgkin, 27-39. New Brunswick: Transaction Publishers.

Bruzzi, Stella. 2000. New Documentary: A Critical Introduction. New York: Routledge.

Bújdosó, Bori. Beszélgess a nagyiddal! [Talk to Your Granny!] Nagyi projekt [Granny Project]. https://revizoronline.com/hu/cikk/7559/nagyi-projekt/. Last accessed 27. 08. 2019.

Deák, István. 2002. A jedwabnei tragédia 1941. Kollektív felelősség, kollektív dicsőség [The Tragedy of Jedwabne, 1941. Collective Responsibility and Collective Glory]. http://www.historia.hu/archivum/2002/0208deak.htm. Last accessed 05. 08. 2019.

Elsaesser, Thomas. 2001. Postmodernism as Mourning Work. Screen vol. 42, no. 2, 193-201.

Friedländer, Saul. 1992. Trauma, Transference, and "Working through" in Writing the History of the "Shoah." History and Memory vol. 4, no. 1 (Spring): 39-59.

Friedländer, Saul. 1993. Memory, History, and the Extermination of the Jews of Europe. Bloomington: Indiana University Press.

Gyáni, Gábor. 2013. Nemzet, kollektív emlékezet és public history [Nation, Collective Memory and Public History]. In Nép, nemzet, zsidó [People, Nation, Jew], 173-210. Budapest: Pesti Kalligram Kft.

Győri, Zsolt. 2015. Veteránemlékezet a Gulyás testvérek Én is jártam Isonzónál címú filmjében [Veterans Remembering in the Gulyás Brothers' I Was at the Isonzo, too Film]. Magyar Múvészet no. 3: 160-167.

Heisler, András. 2015. A holokauszt-emlékév mérlege [The Balance of the Holocaust Memorial Year]. Népszabadság, April 08, 2015.

Juhász, Gyula. 1987. „... Békévé oldja” [“... Dissolves it into Peace”]. Filmvilág no. 5: 20-22.

Murai, András. 2015. Szembesítés. Történelmi dokumentumfilmek a rendszerváltás éveiben. [Confrontation. Historical Documentary Films during the Years of the Regime Change]. Apertúra. http://uj.apertura.hu/2015/ osz/murai-szembesites-tortenelmi-dokumentumfilmek-a-rendszervaltozaseveiben/. Last accessed 27. 08. 2019.

Nichols, Bill. 2001. Introduction to Documentary. Bloomington: Indiana University Press. 
Pozsonyi, Janka. 2017. Nincs benne felelősség, csak a játék [There is No Responsibility Here, It is Just a Game]. http://magyar.film.hu/filmhu/magazin/ granny-project-nincs-benne-felelosseg-csak-a-jatek.html. Last accessed 05. 08. 2019.

Rácz, Viktória. 2018. Híd a generációs szakadék felett [A Bridge over the Generation Gap]. Filmtett. https://www.filmtett.ro/cikk/4865/hid-a-generacios-szakadekfelett-revesz-balint-granny-project-nagyi-projekt. Last accessed 27. 08. 2019.

Stőhr, Lóránt. 2011. Feltépett sebek [Ripped Wounds]. Médiakutató no. 3. https:// mediakutato.hu/cikk/2011_03_osz/07_feltepett_sebek. Last accessed 05. 08. 2019.

Szekfü, András. 2014. Hallgatásra ítélve. Beszélgetés Gulyás Gyulával és Gulyás Jánossal [Condemned to Silence. A Conversation with Gyula and János Gulyás]. Filmvilág no. 8: 13-17. 